\title{
Clinical applications of immunoglobulin in neuromuscular diseases: focus on inflammatory myopathies
}

\author{
Aplicações clínicas de imunoglobulina em doenças neuromusculares com foco em \\ miopatias inflamatórias \\ Paulo Victor Sgobbi de Souza, Wladimir Bocca Vieira de Rezende Pinto, Acary Souza Bulle Oliveira
}

\begin{abstract}
During recent years, an increasing number of neuromuscular diseases have been recognized either to be caused primarily by autoimmune mechanisms, or to have important autoimmune components. The involved pathophysiological mechanisms and clinical manifestations have been better recognized and many of these disorders are potentially treatable by immunosuppression or by immunomodulation with intravenous immunoglobulin (IVlg). IVlg has been tried in a variety of immune-mediated neurological diseases, being target of widespread use in central and peripheral nervous systems diseases. Objective: To give an overview of the main topics regarding the mechanism of action and different therapeutic uses of IVlg in neurological practice, mainly in neuromuscular diseases.
\end{abstract}

Keywords: immunoglobulin, neuromuscular diseases, autoimmunity, inflammatory myopathy.

\section{RESUMO}

Nos últimos anos, um número progressivo de doenças neuromusculares passaram a ser reconhecidas tanto por ser causadas por mecanismos autoimunes ou por envolver importantes componentes autoimunes. Os mecanismos fisiopatológicos e as manifestações clínicas envolvidos têm sido mais bem reconhecidos e muitas de tais doenças são potencialmente tratáveis por imunossupressão ou imunomodulação com imunoglobulina intravenosa (IVlg). IVlg vem sendo utilizada em uma variedade de doenças neurológicas imunomediadas, sendo alvo de amplo uso em doenças dos sistemas nervosos central e periférico. Objetivo: Oferecer uma visão global sobre os principais tópicos relacionados aos mecanismos de ação e aos diferentes usos terapêuticos da IVIg na prática neurológica, principalmente em doenças neuromusculares.

Palavras-chave: imunoglobulina, doenças neuromusculares, autoimunidade, miopatia inflamatória.

The number of inflammatory neurological diseases has significantly increased in the last decades. The involved pathophysiological mechanisms and clinical manifestations have been better recognized and in proportion has been increasing the number of different therapeutic proposals, notably in the field of immune-mediated neurological diseases. Old neurological disorders essentially credited as primarily degenerative and infectious diseases evinced the importance of its inflammatory and immune-mediated components in its pathophysiology. Treatments formely used for autoimmune inflammatory diseases and primary immunodeficiencies have become frequently used in various neurological diseases and in a wide different group of contexts, highlighting the immunomodulatory drugs, corticosteroids, plasmapheresis and intravenous immunoglobulin (IVIg $)^{1}$. In this perspective, the use of IVIg represents an important therapeutic perspective in large amounts of immune-mediated neurological diseases, being target of widespread use in central and peripheral nervous systems diseases. The main focus of this review is to highlight the main mechanisms of action and current uses of IVIg in neurological practice.

\section{MECHANISMS OF ACTION AND BASIS OF CURRENT USE OF IMMUNOGLOBULIN}

IVIg preparation offers a mix of concentrated formulations of human $\operatorname{IgG}$ prepared by industrial fractionation of different pools of plasma donations with functionally and structurally intact immunoglobulin and its associated 
antibody profiles. More than 30 different preparations of intravenous immunoglobulin are currently available for use in different settings and clinical conditions. In primary and secondary antibody immunodeficiencies, immunoglobulin replacement therapy originally required monthly intravenous applications of 400 to $600 \mathrm{mg} / \mathrm{kg}$ associated with serum IgG level controls. Nowadays anti-inflammatory and immunomodulatory actions are commonly observed at higher doses $(400 \mathrm{mg} / \mathrm{kg}$ per day, most commonly for 5 days, or $1 \mathrm{~g} / \mathrm{kg}$ per day for 2 days). This total dose of $2 \mathrm{~g} / \mathrm{kg}$ is the most common applied therapeutic strategy to treat different immunomediated neurological disorders ${ }^{2}$, since the first clinical attempts with refractory chronic polymyositis ${ }^{3}$. Subcutaneous administration has been also previously used, temporarily abandoned due to complications from sterile abscesses in the past, and currently used safely as an alternative for prophylaxis in primary immunodeficiencies ${ }^{2}$. It is not wellestablished for use in neurological autoimmune diseases.

Drug adverse effects are commonly described affecting up to $15 \%$ of patients with intravenous infusion of immunoglobulin, generally in a mild early-onset non-anaphylactoid fashion with nonspecific systemic clinical complaints, including headache, drowsiness, tachycardia and hypotension. Some of theses cases are self-limiting and require the stop or prompt slowing of immunoglobulin infusion rate or even stoppage and the use of symptomatic therapy, mainly represented by corticosteroids, nonsteroidal antiinflammatory drugs and intravenous hydration. There is also the description of earlyonset severe anaphylaxis commonly associated with IgA deficiency in serum levels lesser than $0.05 \mathrm{~g} / \mathrm{L}$. Acute renal failure (not related to sorbitol-based formulations), sepsis, transient neutropenia, disseminated intravascular coagulation, hepatitis $\mathrm{C}$ viral and parvovirus B19 infection, Transfusion-associated Acute Lung Injury (TRALI), aseptic meningitis, thrombotic events (deep venous thrombosis, pulmonary embolism, acute myocardial infarction, stroke), pseudohyponatremia and late-onset arthritis, aseptic meningitis and neurodegeneration have also been described in related to the use of $\mathrm{IVIg}^{2,4}$.

Although initially applied for patients with specific primary immunodeficiency diseases, IVIg is widely used nowadays for different groups of clinical conditions (Table 1), mainly hematological, dermatological and autoimmune diseases $^{5,6,7,8,9}$. Despite the seemingly supplementation and prophylatic mechanism involved with its classical use in some immunodeficiencies, the clinical response observed in different contexts of diverse pathophysiological autoimmunity enabled the development of different hypotheses regarding the drug's mechanism of action. This review covers some of the key mechanisms previously described.

The set of immunomodulatory mechanisms related to the action of IVIg is variable, complex and not well established, and there is still controversial points between clinical practice and experimental studies ${ }^{6}$. It is also important to emphasize that the inflammatory activities of immunoglobulin depend mainly on its concentration, producing paradoxical responses of pro- and anti-inflammatory actions ${ }^{10}$. Its uses comprise different groups of actions mediated via the variable regions Fab (fragment, antigen-binding region in the arms of the $\mathrm{Y}$ arm) and the direct effect of Fc region (fragment, crystallizable region in the base of the $\mathrm{Y}$ arm), by complement binding in the Fc region, and by other immunomodulatory substances present in the preparations of intravenous immunoglobulin ${ }^{6,11}$. There is direct interaction between the Fc portion of immunoglobulins with their receptors yielding the well-known immunoregulatory effects. It also occurs in modulating effector functions and activation of B and T lymphocytes, neutralization of pathogenic autoantibodies, interference with the process of antigen presentation and the complement and cytokine-dependent overall anti-inflammatory effect ${ }^{12}$. Inhibitory Fc-gamma receptor FcgammaRIIB, expressed on myeloid cells and B cells, is required for the anti-inflammatory activity of intravenous

Table 1. Major non-neurological diseases for which intravenous immunoglobulin has been previously used f $^{5,6,78,9}$.

\begin{tabular}{|c|c|}
\hline \multicolumn{2}{|c|}{ Clinical diseases and intravenous immunoglobulin use } \\
\hline Hematologic diseases & $\begin{array}{l}\text { Idiopathic thrombocytopenic purpura; autoimmune hemolytic anemia; hemolytic disease of the newborn with } \\
\text { severe hyperbilirubinaemia; parvovirus B19-associated aplasia; immune neutropenia; thrombotic } \\
\text { thrombocytopenic purpura; acquired von Willebrand disease; acquired factor VIII inhibitor; prophylaxis (for graft- } \\
\text { versus-host disease and infectious) after bone marrow transplantation (in recipients older than } 20 \text { years of age) and } \\
\text { for B-cell chronic lymphocytic leukaemia }\end{array}$ \\
\hline $\begin{array}{l}\text { Rheumatologic } \\
\text { diseases }\end{array}$ & $\begin{array}{l}\text { Kawasaki disease, systemic lupus erythematosus (hematological, central and peripheral nervous } \\
\text { system, serositis and renal activities), fibromyalgia }\end{array}$ \\
\hline Dermatologic diseases & $\begin{array}{l}\text { Autoimmune bullous disease (bullous pemphigoid, pemphigus vulgaris and foliaceus, linear lgA } \\
\text { disease), erythema multiforme, toxic epidermal necrolysis, chronic urticaria, pyoderma } \\
\text { gangrenosum, scleromyxedema, atopic dermatitis }\end{array}$ \\
\hline $\begin{array}{l}\text { Gastroenterological } \\
\text { diseases }\end{array}$ & Severe Clostridium difficile colitis, inflammatory bowel disease \\
\hline $\begin{array}{l}\text { Primary } \\
\text { immunodeficiencies }\end{array}$ & $\begin{array}{l}\text { Prophylaxis in hypogammaglobulinaemia; severe combined Immunodeficiency; X-linked agammaglobulinaemia, } \\
\text { common variable immunodeficiency disorders, immunodeficiency with hyper-lgM syndrome, Wiskott-Aldrich } \\
\text { syndrome, ataxia-telangiectasia (Louis-Bar syndrome), DiGeorge syndrome, Good syndrome (thymoma with } \\
\text { immunodeficiency), X-linked lymphoproliferative syndrome, hyper-lgE syndrome }\end{array}$ \\
\hline Miscellaneous & $\begin{array}{l}\text { Prophylaxis in children with chronic HIV infection; autoimmune uveitis; Birdshot retinochoroidopathy, } \\
\text { streptococcal toxic schock syndrome, systemic vasculitis, severe drug-induced antibody deficiency }\end{array}$ \\
\hline
\end{tabular}


immunoglobulin ${ }^{13}$. For example, impaired expression of the inhibitory FcgammaR in chronic inflammatory demyelinating polyneuropathy (CIDP) can be partially restored by immunoglobulin treatment and changing the impaired late B cell differentiation step checkpoint. In the context of immunoglobulin's V-region dependent mechanisms of action, in the case of medium-sized vessel vasculitis, an important reduction in serum cytokines levels has been established ${ }^{14}$.

In the context of the overall anti-inflammatory effect, for example, it has also been proved that immunoglobulin use in polymyositis inhibits TNF-alpha, interleucin-1 and the uptake of $\mathrm{C} 3$ for deposition of complement membrane attack complex on the endomysial capillaries, and also blocks the process of macrophageal Fc receptor-mediated phagocytosis $^{15}$. Other mechanism proposed involving the immunoglobulin Fc region in dermatomyositis involves also the binding of $\mathrm{C}_{4} \mathrm{~b}^{14}$. It is also established new antiinflammatory properties of the minor fraction of sialylated immunoglobulin molecules ${ }^{10}$.

Furthermore, in addition to the more classical mechanisms, recent studies also showed that immunoglobulin products contains specific anti-Tau antibodies, suggesting the possibility of applying this drug for patients with mild to moderate Alzheimer's disease ${ }^{16}$, although no clinical evidence was obtained from former clinical trials and experimental studies from over a decade ${ }^{17}$. It is believed, though mainly hypothetical, that human anti-amyloid-beta antibodies may also play an important role in the clearance of aggregates of amyloid proteins in the elderly with Alzheimer's disease ${ }^{18}$. Other proposed associated mechanism of action involves target-site integrins on extracellular matrix and cell surfaces ${ }^{19}$, lymphocyte and monocyte apoptosis induction ${ }^{2}$, modulation of regulatory T cells, inhibition of differentiation and maturation of dendritic cells, and apoptosis of B and $\mathrm{T}$ cells using Fas receptor-related pathways ${ }^{20}$.

\section{IVIG - PREPARATIONS}

There are different preparations of IVIg available for use in clinical practice (Table 2).

\section{Classical and current neurological indications}

Its use has been widespread in other specialties than Neurology (Table 1) 1,6,7,9, although US Food and Drug Administration approved the use of IVIg in few conditions, including Allogeneic bone marrow transplantation, chronic lymphocytic leukemia, common variable immunodeficiency, pediatric HIV type I infection, Kawasaki disease, immunemediated thrombocytopenia, kidney transplantation (with high antibody recipiente or with an $\mathrm{ABO}$ incompatible donor), primary immunodeficiency disorders with defects in humoral immunity and hematopoietic stem cell transplantation (patients older than 20 years). In Brazil, regarding the autoimmune neurological conditions, the Agência Nacional de Vigilância Sanitária (ANVISA) approved the use of IVIg in only five conditions (ANVISA Public Consultation, number 36, 20/05/2004; and Ministry of Health of Brazil, Ordinance number 3,439, 11/11/2010): Guillain-Barré syndrome, myasthenia gravis, juvenil dermatomyositis, other dermatomyositis, and polymyositis. Although commonly used among different neurological contexts (Table 3), immunoglobulin use has been studied in a proper manner in neuromuscular disorders ${ }^{2,18,21,22,23,24,25,26}$. Neuromuscular junction diseases have been target of studies with different immunomodulatory therapies, including the isolated and combined use of immunoglobulin. In myasthenia gravis, IVIg has its use approved in cases of rapidly progressive disease (severe clinical manifestation or in severe exacerbation), myasthenic crisis (similarly to the plasma exchange), preparation of patients with weakness for surgeries (including therapeutic thymectomy) and as adjuvant in cases of chronic oral immunossupressive therapy aiming the reduction of cumulative dose and minimizing its long-term side effects ${ }^{2,27}$. There is no formal indication for chronic maintenance therapy alone. In other neuromuscular junction disorders, like Lambert-Eaton myasthenic syndrome, case reports and small placebo-controlled study indicate the possibility of mild to moderate improvement in clinical and electroneuromyographic parameters (mainly the amplitude of the resting CMAP) in patients refractory to immunossupressive drugs ${ }^{28}$.

Among all peripheral neuropathy and polyradiculoneuropathy, most studies with promising and positive results with

Table 2. Different preparations of immunoglobulin available and their biochemical and pharmacokinetic properties.

\begin{tabular}{|c|c|c|c|c|c|c|c|}
\hline Properties & Gammagard & Gammar-P & Gamunex & Octagam & Flebogamma & $\begin{array}{l}\text { Sandoglobulina } \\
\text { Privigen }\end{array}$ & Kiovig \\
\hline Laboratory & ARC/Baxter & Aventis & Bayer & Octapharma & Grifols & CSL Behring & Baxter \\
\hline Form & Powder & Powder & Liquid & Liquid & Liquid & Liquid & Liquid \\
\hline Concentration (\%) & 5-10 & 5 & 10 & 5 & 5-10 & 10 & 10 \\
\hline Osmolarity & $125-636$ & 309 & 258 & $310-380$ & $327-342$ & 320 & 309 \\
\hline $\operatorname{lgA}(\mu \mathrm{g} / \mathrm{mL})$ & $<2.4$ & $<25$ & 46 & $<0.4$ & $<0.003$ & $<0.025$ & $<0.14$ \\
\hline Stabilizer & Glucose (20-40 mg) & Sucrose (50 mg) & None & Maltose & Sorbitol 5\% & Proline & Sucrose \\
\hline Salt $(\mathrm{mg} / \mathrm{mL})$ & 8.5-17 & 5 & Trace & 0 & $<3.2$ & $<1$ & 5 \\
\hline Time of infusion (hours) & $1.2-5$ & $5-6$ & 2 & $4-6$ & 3.1 & $1.2-5$ & $5-6$ \\
\hline $\mathrm{pH}$ & $6.4-7.2$ & $6.4-7.2$ & $4-4.5$ & $5.1-6$ & 5.6 & 4.8 & $6.4-7.2$ \\
\hline
\end{tabular}


Table 3. Major groups of neurological diseases for which intravenous immunoglobulin has been studied in clinical trials, case reports and currently used in practice 2,18,21,22,23,24,25,26.

Intravenous immunoglobulin and groups of neurological diseases

Neuromuscular Diseases

Inflammatory myopathies (dermatomyositis, polymyositis, inclusion body myositis - sporadic and autosomal recessive hereditary type), neuromuscular junction disorders (myasthenia gravis class II/II Osserman-Genkins classification, myasthenic crisis or exacerbation), peripheral neuropathy and polyradiculoneuropathy (proximal subacute diabetic neuropathy, multifocal motor neuropathy, Guillain-Barré syndrome and variants, Chronic inflammatory demyelinating polyneuropathy, critical illness polyneuropathy and/or myopathy, autoimmune autonomic ganglionopathy), motor neuron disease (post-Polio syndrome), others (complex regional pain syndrome type 1, formerly known as reflex sympathetic dystrophy or Sudeck's atrophy; resistant neuropathic pain)

Dementia and cognitive Alzheimer's disease, Mild cognitive impairment

disorders

Cerebellar ataxias

Demyelinating diseases

Paraneoplastic neurological disorders

Miscellaneous
Spinocerebellar ataxias, sporadic cerebellar ataxia (including the cerebellar predominant variant of multiple system atrophy)

Relapsing-remitting multiple sclerosis, acute disseminated encephalomyelitis, anti-aquaporin 4 antibody positive neuromyelitis optica spectrum disorder, optic neuritis, chronic relapsing inflammatory optic neuropathy (CRION)

Limbic encephalitis (anti-VGKC, anti-Hu, anti-Ma2, anti-CV2/CRMP5), subacute sensory neuronopathy (anti-Hu, anti-CV2/CRMP5), opsoclonus-myoclonus (anti-Ri, anti-Hu, anti-Ma2, anti-amphiphysin), cerebellar paraneoplastic degeneration (anti-Yo, anti-Hu, anti-Tr, anti-CV2/CRMP5, anti-VGCC), Lambert-Eaton myastenic syndrome (anti-VGCC), peripheral nerve hyperexcitability in Isaacs' syndrome (anti-VGKC) HIV-associated vacuolar myelopathy, Japanese encephalitis, Rasmussen encephalitis, refractory autoimmune epilepsy with partial seizures, Stiff-person syndrome, PANDAS syndrome (pediatric autoimmune neuropsychiatric disorders associated with streptococcal infections), ischaemic stroke, Susac's syndrome, narcolepsy immunoglobulin involved patients with multifocal motor neuropathy (MMN), Guillain-Barré syndrome (GBS) and variants, and CIDP. In CIDP with moderate to severe motor disability, IVIg is proven as the first-line immunotherapy, including for maintenance treatment associated with immunomodulatory drugs ${ }^{2,13,22}$. In GBS, similarly to the observed effect of plasma exchange therapy, equal responses and effects are observed with IVIg in the standard classical dose of $400 \mathrm{mg} / \mathrm{kg}$ per day for 5 days. Its use as immunotherapy in GBS remits to 1988. However, it is not established the advantage of one method instead of the other in cases of recurrence or no response if another course should be given or plasma exchange performed ${ }^{2,22}$. In MMN, it is established in different randomized controlled trials the first-line treatment function of IVIg, using the same initial dose of GBS, irrespective of the presence of positivity for anti-GM1 ganglioside antibody or conduction block ${ }^{2,22}$. Refractory cases or partial responses are indicative of the possible use of immunomodulatory drugs. In paraproteinaemic demyelinating neuropathies, especially in cases of IgM monoclonal gammopathy of undetermined significance, immunoglobulin use represents the initial first-line treatment ${ }^{2}$.

In the case of motor neuron disease, there is no therapeutic improvement after high-dose intravenous immunoglobulin use in amyotrophic lateral sclerosis ${ }^{28}$, although moderate motor effects have been evinced in individual cases of post-polio syndrome with rapid weakness and amyotrophy progression ${ }^{2}$. Following the text the use of immunoglobulin for inflammatory myopathies is discussed in detail.

\section{Clinical applications of immunoglobulin in inflammatory myopathies}

Inflammatory myopathies represent a wide group of heterogeneous neuromuscular diseases, including mainly acquired immune and infectious myopathies. The most important clinical conditions include polymyositis, inclusion body myositis and dermatomyositis. Several clinical and pathological acquired variants, including paraneoplastic and other myopathies related to autoimmune diseases, have been described, however hereditary conditions are also found. Specific pathological, clinical and currently radiological criteria and findings are described in each of this condition. In general, in summary, the treatment of most autoimmune inflammatory forms depends on the use of oral corticosteroids or maintenance pulse, in addition to any combination with immunomodulators such as cyclosporine, methotrexate and azathioprine ${ }^{29}$. It is exactly for cases in which there is prolonged use of these therapies, in cases of serious adverse events or in clinical refractory or partially responsive disease that IVIg has been studied and applied.

The treatment of inflammatory myopathies with IVIg has been mostly empirical. In recente years several open studies have indicated a favorable effect mainly for dermatomyositis, in which it has proved to increase clinical improvement and muscle strength in cases of resistance to immunossupressive and immunomodulatory drugs and in severe presentations, generally in association with prednisone $e^{2}$. The same results were less pronounced and evinced for polymyositis, in which few studies showed the importance for reduction of corticosteroid dosage in chronic refractory disease, especially in 
cases without response to steroid immunosupressive treatment $^{2}$. In sporadic inclusion body myositis, it has been proved that cases with severe dysphagia could benefit from intravenous immunoglobulin, even though a formal recommendation is still needed ${ }^{2,22,30,31,32}$. Although clinical response was noticed in the cases described, molecular immune mechanisms, activated immune cells and hystopathological muscle changes were still equally represented before and after immunoglobulin therapy ${ }^{33}$.

\section{FINAL REMARKS}

The use of intravenous immunoglobulin has been proven effective in various situations within the neurological practice, notably in neuromuscular diseases. Few randomized multicenter clinical trials to study the effectiveness of the drug in larger samples of patients have been made for most diseases. Positive effects are demonstrated in open studies in dermato- and polymyositis, myasthenia gravis, and inflammatory neuropathies. Properly conducted randomized clinical trials demonstrating the effect of IVIg are available in GBS, CIDP, dermatomyositis, and smaller ones in multifocal motor neuropathy. There is no doubt as to the necessity to enhance the therapeutic role of this medication in neurological diseases, especially in cases of severe disease or refractoriness to the usual therapeutic modalities. It is also outstanding the restricted indicators for use of IVIg in neurological disorders in Brazil, limited to SGB, myasthenia gravis, juvenile dermatomyositis, other dermatomyositis and polymyositis.

\section{References}

1. Elovaara I, Hietaharju A. Can we face the challenge of expanding use of intravenous immunoglobulin in neurology? Acta Neurol Scand. 2010;122(5):309-15. http://dx.doi.org/10.1111/j.1600-0404.2009.01317.x

2. Elovaara I, Apostolski S, Doorn P, Gilhus NE, Hietaharju A, Honkaniemi $J$ et al. EFNS guidelines for the use of intravenous immunoglobulin in treatment of neurological diseases: EFNS task force on the use of intravenous immunoglobulin in treatment of neurological diseases. Eur J Neurol. 2008;15(9):893-908. http://dx.doi.org/10.1111/ j.1468-1331.2008.02246.x

3. Roifman CM, Schaffer FM, Wachsmuth SE, Murphy G, Gelfand EW. Reversal of chronic polymyositis following intravenous immune serum globulin therapy. JAMA. 1987;258(4):513-5. http://dx.doi.org/ 10.1001/jama.1987.03400040111034

4. Orbach H, Katz U, Sherer Y, Shoenfeld Y. Intravenous immunoglobulin: adverse effects and safe administration. Clin Rev Allergy Immunol. 2005;29(3):173-84. http://dx.doi.org/10.1385/criai:29:3:173

5. Schwab I, Nimmerjahn F. Intravenous immunoglobulin therapy: how does IgG modulate the immune system? Nat Rev Immunol. 2013;13(3):176-89. http://dx.doi.org/10.1038/nri3401

6. Lemieux R, Bazin R, Néron S. Therapeutic intravenous immunoglobulins. Mol Immunol. 2005;42(7):839-48. http://dx.doi.org/10.1016/j. molimm.2004.07.046

7. Orange JS, Hossny EM, Weiler CR, Ballow M, Berger M, Bonilla FA et al. Use of intravenous immunoglobulin in human disease: a review of evidence by members of the Primary Immunodeficiency Committee of the American Academy of Allergy, Asthma and Immunology. J Allergy Clin Immunol. 2006;117(4 Suppl):S525-53. http://dx.doi.org/ 10.1016/j.jaci.2006.01.015

8. Gürcan HM, Ahmed AR. Efficacy of various intravenous immunoglobulin therapy protocols in autoimmune and chronic inflammatory disorders. Ann Pharmacother. 2007;41(5):812-23. http://dx.doi.org/ 10.1345/aph.1k037

9. Gelfand EW. Intravenous immune globulin in autoimmune and inflammatory diseases. N Engl J Med. 2012;367(21):2015-25. http://dx.doi.org/10.1056/nejmra1009433

10. Durandy A, Kaveri SV, Kuijpers TW, Basta M, Miescher S, Ravetch JV et al. Intravenous immunoglobulins: understanding properties and mechanisms. Clin Exp Immunol. 2009;158:2-13. http://dx.doi.org/ 10.1111/j.1365-2249.2009.04022.x

11. Baerenwaldt A, Biburger M, Nimmerjahn F. Mechanisms of action of intravenous immunoglobulins. Expert Rev Clin Immunol. 2010;6(3):425-34. http://dx.doi.org/10.1586/eci.10.9
12. Bayry J, Misra N, Latry V, Prost F, Delignat S, Lacroix-Desmazes S et al. Mechanisms of action of intravenous immunoglobulin in autoimmune and inflammatory diseases. Transfus Clin Biol. 2003;10(3):165-9. http://dx.doi.org/10.1016/s1246-7820(03)00035-1

13. Tackenberg B, Nimmerjahn F, Lünemann JD. Mechanisms of IVIG efficacy in chronic inflammatory demyelinating polyneuropathy. J Clin Immunol. 2010;30(1 Suppl):S65-9. http://dx.doi.org/10.1007/s10875010-9398-1

14. Pyne D, Ehrenstein M, Morris V. The therapeutic uses of intravenous immunoglobulins in autoimmune rheumatic diseases. Rheumatology (Oxford). 2002;41(4):367-74. 10.1093/rheumatology/41.4.367

15. Dalakas MC. Clinical benefits and immunopathological correlates of intravenous immune globulin in the treatment of inflammatory myopathies. Clin Exp Immunol. 1996;104 Suppl:55-60.

16. Smith LM, Coffey MP, Klaver AC, Loeffler DA. Intravenous immunoglobulin products contain specific antibodies to recombinant human tau protein. Int Immunopharmacol. 2013;16(4):424-8. http://dx.doi. org/10.1016/j.intimp.2013.04.034

17. Loeffler DA. Intravenous immunoglobulin and Alzheimer's disease: what now? J Neuroinflammation. 2013;10(1):70. http://dx.doi.org/ 10.1186/1742-2094-10-70

18. Hughes RAC, Dalakas MC, Cornblath DR, Latov N, Weksler ME, Relkin N. Clinical applications of intravenous immunoglobulins in neurology. Clin Exp Immunol. 2009;158(Suppl):34-42. http://dx.doi.org/10.1111/ j.1365-2249.2009.04025.x

19. Blank M, Nur I, Toub O, Maor A, Shoenfeld Y. Toward molecular targeting with specific intravenous immunoglobulin preparation. Clin Rev Allergy Immunol. 2005;29(3):213-7. http://dx.doi.org/10.1385/ criai:29:3:213

20. Novaretti MC, Dinardo CL. Immunoglobulin: production, mechanisms of action and formulations. Rev Bras Hematol Hemoter. 2011;33(5):377-82. http://dx.doi.org/10.5581/1516-8484.20110102

21. Dalakas MC. Intravenous immunoglobulin in autoimmune neuromuscular diseases. JAMA. 2004;291(19):2367-75. http://dx.doi.org/10.1001/ jama.291.19.2367

22. Stangel M. New advances in the treatment of neurological diseases using high dose intravenous immunoglobulins. Ther Adv Neurol Disord. 2008;1 (2):52-61. http://dx.doi.org/10.1177/1756285608095747

23. Gold R, Stangel M, Dalakas MC. Drug Insight: the use of intravenous immunoglobulin in neurology-therapeutic considerations and practical issues. Nat Clin Pract Neurol. 2007;3(1):36-44. http://dx.doi.org/ 10.1038/ncpneuro0376 
24. Wiles C, Brown P, Chapel H, Guerrini R, Hughes RA, Martin TD et al. Intravenous immunoglobulin in neurological disease: a specialist review. J Neurol Neurosurg Psychiatry. 2002;72(4):440-8. http://dx. doi.org/10.1136/jnnp.72.4.440

25. Cursiefen S, Mäurer M. Current use of immunoglobulins in neurology. Nervenarzt. 2008;79(2 Suppl):67-74. 10.1007/s00115-008-2461-y

26. Winkelmann A, Zettl UK. Use of intravenous immunoglobulin in the treatment of immune-mediated demyelinating diseases of the nervous system. Curr Pharm Des. 2012;18(29):4570-82. http://dx. doi.org/10.2174/138161212802502314

27. Skeie GO, Apostolski S, Evoli A, Gilhus N/e, Illa I, Harms L et al. Guidelines for the treatment of autoimmune neuromuscular transmission disorders. Eur J Neurol. 2010;17(7):893-902. http://dx.doi. org/10.1111/j.1468-1331.2010.03019.x

28. Dalakas MC, Stein DP, Otero C, Sekul E, Cuple EJ, McCrosky S. Effect of high-dose intravenous immunoglobulin on amyotrophic lateral sclerosis and multifocal motor neuropathy. Arch Neurol. 1994;51(9):861-4. http://dx.doi.org/10.1001/archneur.1994.00540210031010
29. Dalakas MC. Review: an update on inflammatory and autoimmune myopathies. Neuropathol Appl Neurobiol. 2011;37(3):226-42. http://dx.doi.org/10.1111/j.1365-2990.2010.01153.x

30. Illa I. IVIg in myasthenia gravis, Lambert Eaton myasthenic syndrome and inflammatory myopathies: current status. J Neurol. 2005;252(1 Suppl):i14-8. http://dx.doi.org/10.1007/s00415005-1104-5

31. Pul R, Stangel M. Using immunoglobulins in muscular disease treatment. Expert Opin Biol Ther. 2008;8(8):1143-50. 10.1517/ 14712598.8.8.1143

32. Dalakas MC. High-dose intravenous immunoglobulin in inflammatory myopathies: experience based on controlled clinical trials. Neurol Sc. 2003;24(4 Suppl):S256-9. http://dx.doi.org/10.1007/s10072-003-0090-6

33. Helmers SB, Dastmalchi M, Alexanderson H, Nennesmo I, Esbjörnsson M, Lindvall $B$ et al. Limited effects of high-dose intravenous immunoglobulin (IVIG) treatment on molecular expression in muscle tissue of patients with inflammatory myopathies. Ann Rheum Dis. 2007;66(10):1276-83. http://dx.doi.org/10.1136/ard.2006.058644 